\title{
Financial Performance of Banks in Lebanon: Conventional vs Islamic
}

\author{
Boutheina HASHEM $^{1}$, Hiyam SUJUD ${ }^{1}$ \\ ${ }^{1}$ Finance Department, Faculty of Business, 1st Branch, Lebanese University, Lebanon \\ Correspondence: Boutheina HASHEM, Finance Department, Faculty of Business, 1st Branch, Lebanese \\ University, Lebanon.
}

Received: December 18, 2018

Accepted: January 7, 2019

Online Published: January 11, 2019

doi:10.5539/ibr.v12n2p40

URL: https://doi.org/10.5539/ibr.v12n2p40

\begin{abstract}
This study compares the performance of Islamic and conventional banking in Lebanon in terms of Return on Assets and Return on Equity over the period 2012-2016. Moreover, it examines whether the internal characteristics of the bank may explain the difference in profitability between two types of banking transactions. In addition, the results of the study are analyzed using a regression analysis applied to a sample of both Islamic and conventional banks to investigate the effects of these variables on bank performance. Furthermore, results show that Islamic banks in Lebanon have better asset adequacy compared to conventional banks. However, conventional banks are better in liquidity and are on an average more profitable than Islamic ones. It is worthy to indicate that the Islamic banking industry in Lebanon is still in its infancy and only very few of the banks were active in this sector.
\end{abstract}

Keywords: conventional banks, Islamic banks, profitability indicators, ROA, ROE

\section{Introduction}

The banking sector is considered one of the pioneer sectors in modern economies and it is one of the main engines due to the important role it plays in mobilizing domestic and foreign savings. It contributes to financing investments that are the mainstay of economic activity. It also plays an active role in meeting the requirements of contemporary life by facilitating transactions between individuals and community institutions.

The banks have developed and diversified their forms according to the specialization of the activities, the work they perform, and the laws and rules governing them. Also, the traditional banks have proved their role in the financial intermediation, and the years have passed and have gained a lot of experiences through practices. The Islamic banks, which today are considered the most prominent event in the field of banking within and outside the Islamic world during the past three decades, have emerged as a reality that offers many different investment and financing methods than traditional banks. These banks have become widely known and are increasing year after year through a network of more than 60 Islamic and non-Islamic countries, bringing the number of Islamic institutions and banks in the world to more than 1400 by the end of 2018 (according to the World Competitiveness Report for Islamic Banks). Despite all this, Islamic banks are facing many challenges, and perhaps the most serious challenge faced by them is the traditional banks to open windows for Islamic financial and banking products. Since these banks have the oldest history, experience in banking operations will be more efficient. There is no doubt that one of the most important practical strategies to meet this challenge is that Islamic banks should offer their banking services with high efficiency, and should not be less than the efficiency of banking service provided by conventional banks. Therefore, the Islamic bank can achieve this be diversifying their products from direct and indirect investments at the level of inputs or by reducing the cost of their services.

The evaluation of financial performance in banks is a very important issue, especially for the time being, and the issue of assessing the performance of Lebanese banks is a necessary and urgent process for the progress and prosperity of the Lebanese banking sector, which has affected the efficiency and performance of the banks. This requires evaluation in many aspects, especially the financial aspect, to identify strengths and weaknesses, and to find appropriate solutions to overcome the weaknesses. Thus, this requires a set of tools, methods, and techniques that facilitate the evaluation process, including analysis using indicators and financial ratios.

Most of the studies that evaluate the performance of Islamic banks with conventional banks are used to identify their performance and to ascertain whether or not they can compete with traditional banks using the method of comparative financial analysis. This is because of the different nature of the two types of banks and the different 
financial statements of each type. Common indicators are usually selected using the elements and components of the financial statements issued by Islamic banks and conventional banks. Since the above statistics show that the Islamic finance is one of the fast-growing segments in the international finance and it plays a significant role in their respective economies, our study's main goal is to carry out a comparative study empirically to find out the profitability of Islamic and conventional banks in Lebanon within the period of 2012-2016.

\section{Literature Review}

Al-Sukhari (2017) Study: Evaluation of the Financial Function of Islamic Banks and Traditional Banks - A Comparative Study using the Financial Ratios of a Sample of Banks Operating in Algeria during the Period (2010 - 2015). This study aimed to evaluate and compare the financial performance of the Islamic and traditional banks operating in Algeria, using a set of financial indicators that fall under the indicators of profitability, liquidity, activity (investing money), and solvency index. The study was conducted on four traditional banks operating in Algeria and the Islamic Bank, Al Baraka Bank of Algeria, during the period (2010-2015). The T-test was used to examine the differences between the average performance ratios of $\mathrm{Al}$ Baraka Bank and conventional banks. The study found that Al Baraka Bank enjoys high liquidity and is more profitable than conventional banks. On the other hand, activity indicators showed that conventional banks are more active than Islamic banks and the safety index showed that both types of banks enjoy an acceptable financial solvency. The statistical study also found that there are significant differences between the performance of Islamic banks and traditional banks in terms of profitability, liquidity, and activity except for safety and solvency index. The study proved that there is no difference of statistical significance. The study recommended that the Islamic banks should pay attention to the issue of the investment of funds and taking care of this aspect which is a priority on its level. Consequently, there is the need to develop new and varied investment methods in Islamic banks adapted to the desires of customers to exploit them to employ their resources and make profits that are low when compared to conventional banks. In addition, the traditional banks make better use of their resources and they control operating costs.

Ragheb Al-Ghussein and Mohammed Ammar Nshwati (2014) Study: Evaluation of the Financial Performance of jordanian Islamic and Traditional Banks. The objective of this study was to evaluate the financial performance of the Islamic and traditional Jordanian banks and compare them using the Camel model during the period of 2006-2012. It aims to study the extent of the financial performance reflected in the public confidence level. All Islamic and traditional banks operating in Jordan were selected as sample for the study, represented by 13 traditional banks and Islamic banks. The t- test was used to obtain the differences between the financial ratios and the linear regression analysis to study the effect of the average financial performance separately and collectively on the general confidence level.

The study found that traditional banks perform better than Islamic banks and that the level of public confidence to the customers of Islamic banks arises mainly from their financial performance, contrary to what has been achieved for conventional banks.

Saida Burdima (2014) Study: Assessing Financial Performance of Islamic Banks Using Financial Ratios"Case of Al Baraka International Group from 2011-2013.The study focuses on evaluating the financial performance of Islamic banks. The researcher used a case study on Al Baraka Islamic International Group for the period 2011-2013 using financial ratios. However, the results of the study summarized that the solvency ratios indicate that the Group enjoys a significant solvency margin to ensure that it faces the risk of failure to recover part of its invested funds and the Liquidity ratios indicate that the Group has the liquidity to meet its short-term financial liabilities. The Group achieved a rate of return on equity that can be described as acceptable and which has increased in the years of study.

A Study on the Profitability of the Islamic Banks: Study of its Application to the Group of Islamic Banks for the Period 2009-2013. The study aimed to evaluate the financial performance of ten Islamic banks from six countries for five years for the period 2009-2013 based on a set of indicators and financial ratios, namely: profitability and liquidity indicators, capital adequacy indicators, and activity indicators. The study concluded that Islamic banks are highly efficient in managing operational costs and have high efficiency in generating profits through the size of invested assets but with different capacities for each bank. The study also found that Islamic banks are unable to absorb financing and investment risks and that half of the study sample from banks is unable to manage the liquidity risk.

Anan Fathi Al-Sarouji (2004) Study: Comparative Performance of Islamic and Traditional Banks Using Financial Ratios. This study aimed to compare the performance of the Islamic Bank of Jordan with the performance of conventional banks in Jordan during the period (1992-2001). This was done using nine different 
financial ratios that falls under the ratios of liquidity, profitability, activity and market. A T-test was used to verify that there were significant differences between the performances of these banks. The study found that there are differences of statistical significance in the ratio of liquidity and difference in favor of conventional banks. The profitability ratios revealed no differences, while the percentage of deposit investment and the ratio of return on stock to market value showed no significant differences. The ratio of resource utilization and market value to book value reveals significant differences between Islamic banks and conventional banks. The study also predicted that the performance of the Jordan Islamic Bank would be better than that of conventional banks in terms of profitability in the future.

Brakibah (2014) Study: Evaluation of the Performance of Traditional and Islamic Banks: A Comparative Study of the Return and Risk Methods of the Algerian Popular Loan Bank and Al Baraka Algerian Bank during the Period (2007-2011). The study aimed at evaluating performance in commercial and Islamic banks in terms of return, risk, and comparison in both categories in terms of method and results. To achieve the objective of the study, the annual financial reporting data was used in the period 2007-2012. A case study was adopted using return and risk indicators to assess performance using some indicators such as return on equity, return on assets, profit margin, asset benefit rate, and leverage.

The main findings of the study show that there is a significant difference in performance evaluation indicators applied in conventional and Islamic banks due to the nature of their work. Here, it was found that some risk indicators are shared by the two banks and another is different. It was also found that some performance indicators for conventional banks can be adjusted to suit the performance of Islamic banks. There is no difference between conventional and Islamic banks because of their long experience in the market. The study also recommended the need to improve net income based on the resources that would lead to its increase, the need to diversify the investment portfolio, and to also diversify in the areas of activity and new innovations that are compatible with Islamic law for Islamic banks.

Adegbemi Babatunde and Adekola Olaitan Study: The Performance of Conventional and Islamic Banks in the United Kingdom: A Comparative Analysis. The objective of the study is to compare the efficiency of conventional banks with Islamic banks for the period 2007-2011. The study was conducted on four of the largest Islamic banks and five conventional banks in the UK using financial ratios as performance indicators. The banks' consolidated financial statements were converted to percentages so that they could be compared during the study period. The results of the study showed that conventional banks are more profitable and are able to meet their financial obligations. However, Islamic banks are less exposed to liquidity risk and are more cost effective, while conventional banks rely on external sources of finances. The study recommends the expansion of Islamic banking and management skills development, product diversification, innovation and excellence, and providing and attracting more clients.

Rosnia Masruki et al. (2008) Study: Financial Performance of Malaysian Founder Islamic Banks Versus Conventional Bank, This study aimed at comparing the performance of two Islamic banks in Malaysia (Bank Islam and the Bank Mouaamalat) with the performance of conventional banks over five years (2004-2008) using several key indicators such as profitability, liquidity, and risk. A T-test was applied to examine any significant differences between groups. The study showed that Islamic banks are less profitable than conventional banks but, at the same time, has better liquidity than traditional banks. The reason for the rise in the profitability of traditional banks is the result of higher net financing. Therefore, traditional banks are also faced with higher credit risk than Islamic banks.

By looking at the above previous literature, which focuses on studying and evaluating the financial performance of banks, these studies have been conducted in several countries such as Jordan, Algeria, UK, Malaysia and in several countries. Numerous studies have been carried out, especially between Arab studies and foreign studies, at different time periods, most of which have been in recent years. In addition, most of these studies dealt with the process of evaluating banks using different financial ratios.

Subsequently, most of these studies have yielded results, concluding that:

- There is a difference in performance evaluation indicators applied in traditional banks and in Islamic banks due to the nature of their work.

- Commercial banks are more profitable than Islamic banks.

The present study has been combined with some previous studies in the method of evaluating financial performance where the financial ratios were used in the evaluation process. The regression analysis method, T-test, and correlations were used to determine the differences between the determinant factors of profitability in 
both Islamic and conventional banks. Thus, the points where these studies differed from the current study can be seen from the study sample where the test was conducted.

In this study, we focused on evaluating and comparing the financial performance of Islamic and conventional banks operating in Lebanon using some of the main financial indicators that are important and that are directly related to banking performance, such as Return on Assets and Return on Equity. Here, these indicators revealed the true financial performance of banks and their variants, and it also provides a logical explanation of what this performance entails.

\section{Problem Statement}

The Lebanese banking sector is one of the most important pillars of Lebanon's economy, which is subject to multiple risks reflecting its political and economic reality. There are several factors that directly affect the work of banks, whether they are external factors such as the global financial crisis or internal, represented by the Lebanese economic crisis. This is related to the specificity of the banking system in commercial banks that differ from those in Islamic banks which operates in accordance with the provisions of the Islamic Shariah. Accordingly, the manner of dealing with these previously mentioned conditions and risks by commercial and Islamic banks is different depending on their approach in carrying out their activities. This study comes as an attempt by researchers to compare the performance of commercial banks with Islamic banks in Lebanon by using and analyzing the effect of the following indicators: Return on Assets and Return on Equity. Hence, the problem of the study is to answer the following questions:

1. Is the performance of commercial banks different from the performance of Islamic banks in Lebanon?

2. What are the reasons for the difference, if any, between the performance of commercial banks and the performance of Islamic banks?

\section{Objectives of the Study}

The study aims to achieve the following:

1. To identify the performance of commercial and Islamic banks and the nature of the approach, which were derived from each of them in the provision of banking services.

2. To compare the performance of commercial and Islamic banks through the following indicators: Return on Assets and Return on Equity.

3. To disclose the differences between the performance of commercial and Islamic banks.

\section{Significance of the Study}

The importance of the study arises from the importance of the subject itself in assessing the performance of both Islamic and conventional banks and to highlight and identify the differences between the various levels of performance. It also contributes to shed light on the actual financial performance of some Lebanese banks, in general, by assessing and disclosing of strengths and weaknesses of these banks, and thus make the necessary recommendations on these points.

\section{Research Hypotheses}

The main hypotheses of the study are as follows:

1. There is a significant difference in determinant factors of profitability between conventional banks and Islamic banks.

2. There is a significant factor that affects the profitability of conventional banks and Islamic banks.

\section{Methodology}

To achieve the main objective of the study, which is to compare the financial performance of conventional banks and Islamic banks in Lebanon and to test its hypotheses, the analytical descriptive method was used by using secondary sources of data. The research was based on two sub-sources; the first consisted of books, internet, and previous relevant studies. On the other hand, the second is relying on the websites of traditional and Islamic banks to obtain the annual financial statements for the period (2012-2016), and to obtain the necessary information to calculate the financial indicators used in the research.

\subsection{Sample Selection}

Since the researchers were unable to have access to the necessary information needed for analysis due to some reasons related to some banks, random sampling techniques was used to select data. The sample size consists of 22 conventional banks out of 49 and 3 Islamic banks out of 5 banks operating in Lebanon. 


\subsection{Variables Used}

This study compares the performance of the Lebanese conventional and Islamic Banks in terms of "Return on Equity" and "Return on Assets" using the following internal banks factors:

\begin{tabular}{cc}
\hline Factors & Financial Measurements \\
\hline Capital Adequacy & Total Equity to Total Assets \\
Loans to Assets & Total Loans to Total Assets \\
Deposits to Assets & Total Deposits to Total Assets \\
\hline
\end{tabular}

Definition of Independent and Dependent Variables: These variables are:

Total Equity to Total Assets Ratio: It measures the Bank's capital adequacy and refers to the Bank's ability to absorb losses and deal with risk exposure with shareholders. Hassan and Bashir (2004) found out in their study a positive relationship between total equity to total asset ratio and profitability. Consequently, total equity to total assets is included in this study because it determines the Bank's capital and the Bank's ability to deal with losses with shareholders. Therefore, total equity to total assets is included as an independent variable to study the profitability of Lebanese banks. This ratio is expected to have a positive relationship with performance.

Total Loans to Total Assets Ratio: It measure liquidity of bank assets associated with loans. The higher the total loans to total assets ratio, the lower the liquidity. The bank's operations depend heavily on loans. However, Islamic banks operate on a profit-and-loss basis - interest-free lending. Moreover, some of the previous studies such as Demirguc-Kunt and Huizinga (1997) of traditional banks have found a positive correlation between this ratio and profitability. Therefore, this ratio is included in the profitability study as an independent variable to compare the performance of interest-bearing loans and interest-free lending.

Total Deposits to Total Assets Ratio: It measures the impact of commitments on profitability. Deposits are the main source of bank financing. Bashir and Hasan (2004), in their study, have found a negative correlation between this ratio and profitability. Therefore, this ratio is included in this study as an independent variable and can be compared to other ratios.

Rate of Return on Assets (ROA): This is the net return on assets invested in the bank, which shows the amount of profit achieved by the bank on each dollar invested in its assets. It is therefore an important indicator of Administrative efficiency in the bank (Elyor, 2009). This measure shows the effectiveness of managing the bank's assets for profit (Golin, 2001). The rate of return on assets will be calculated by dividing net profit after tax with the total assets of the bank.

Rate of Return on Equity: This measure refers to net profit earned on shareholders' equity of the bank (Golin, 2001). It shows how effective the bank is in using investors' funds (Elyor, 2009). The rate of return on equity will be calculated by dividing net profit after tax with the total equity.

Conceptual Framework: A conceptual framework is used in the study to outline possible courses of action or to present a preferred approach to an idea or thought (Mackau, 2003). An independent variable is one that is presumed to affect a dependent variable (Dale, 2001). It can be changed as required, and its values do not represent a problem requiring explanation in an analysis, but are taken simply as given. The independent variables in the study were bank specific variables enhancing banks' performance. The dependent variable was profitability of Lebanese banks in terms of Return on Assets and Return on Equity.

Independent Variables

Dependent Variables

$\begin{aligned} & \text { Bank Specific Variables: } \\ & \text { - } \\ & \text { - } \\ & \text { - } \text { Loapital Adequacy } \\ & \text { - Deposits to Assets } \\ &\end{aligned}$

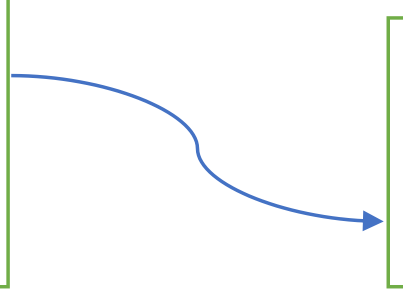

Bank Profitability:

- Return on Assets (ROA)

- $\quad$ Return on Equity (ROE) 


\section{Findings and Analysis}

\section{Independent T-test}

Table 1. Comparison of mean between Islamic and Conventional Banks

\begin{tabular}{llrrrr}
\hline & & Group Statistics & & \\
\hline & Type of bank & $\mathrm{N}$ & \multicolumn{1}{c}{ Mean } & Std. Deviation & Std. Error Mean \\
\hline \multirow{2}{*}{ Return on Assets } & Conventional & 86 & .9774 & 1.10533 & .11919 \\
& Islamic & 11 & -.4173 & 1.92765 & .58121 \\
Return on Equity & Conventional & 86 & 10.5124 & 5.88233 & .63431 \\
& Islamic & 11 & -2.0673 & 9.12718 & 2.75195 \\
Equity / Assets & Conventional & 86 & 10.6888 & 7.51164 & .81000 \\
& Islamic & 11 & 19.5391 & 2.39564 & .72231 \\
Loans / Assets & Conventional & 86 & 30.5901 & 10.57295 & 1.14011 \\
& Islamic & 11 & 12.4318 & 7.12406 & 2.14798 \\
Deposits / Assets & Conventional & 86 & 75.4562 & 16.18962 & 1.74577 \\
& Islamic & 11 & 58.1800 & 20.28213 & 6.11529 \\
\hline
\end{tabular}

The above table shows the comparison of mean between Conventional and Islamic banks in Lebanon. The Total Loan to Total Asset for the conventional banks is higher than the Total Loan to Total Asset for the Islamic banks. The mean of Total Loan to Total Asset for Islamic is 12.4318, while the mean for the Conventional banks is 30.5901. Besides, Deposits to Total Asset of Islamic banks are lower than Conventional banks when it comes to their mean. The mean of Deposits to Total Asset for Islamic banks is 58.1800, while for Conventional banks the mean is 75.4562. However, the mean of Equity to Total Asset for Islamic banks is 19.5391 and 10.6888 for Conventional banks.

So, we can conclude that Islamic banks have better growth for Total Equity to Total Asset rather than Conventional banks.

Table 2. Independent sample T-test

\begin{tabular}{|c|c|c|c|c|c|c|c|c|c|c|}
\hline & & $\begin{array}{l}\text { Leve } \\
\text { for } 1 \\
\text { of } \mathrm{V}\end{array}$ & $\begin{array}{l}\text { s Test } \\
\text { uality } \\
\text { ances }\end{array}$ & & & & $\mathrm{t}$-test for Equ & lity of Mean & & \\
\hline & & $\mathrm{F}$ & Sig. & $\mathrm{T}$ & $\mathrm{df}$ & $\begin{array}{c}\text { Sig. } \\
\text { (2-tailed) }\end{array}$ & $\begin{array}{c}\text { Mean } \\
\text { Difference }\end{array}$ & $\begin{array}{l}\text { Std. Error } \\
\text { Difference }\end{array}$ & $\begin{array}{r}95 \% \text { Confide } \\
\text { of the Dif }\end{array}$ & $\begin{array}{l}\text { e Interval } \\
\text { rence }\end{array}$ \\
\hline & & & & & & & & & Lower & Upper \\
\hline Return on & $\begin{array}{ll}\begin{array}{l}\text { Equal } \\
\text { assumed }\end{array} & \text { variances } \\
\end{array}$ & $\begin{array}{r}6.27 \\
6\end{array}$ & .014 & 3.575 & 95 & .001 & 1.39467 & .39012 & .62018 & 2.16916 \\
\hline Assets & $\begin{array}{l}\text { Equal variances not } \\
\text { assumed }\end{array}$ & & & 2.351 & 10.857 & .039 & 1.39467 & .59330 & .08671 & 2.70263 \\
\hline Return on & $\begin{array}{l}\text { Equal variances } \\
\text { assumed }\end{array}$ & $\begin{array}{r}2.75 \\
0\end{array}$ & .101 & 6.233 & 95 & .000 & 12.57971 & 2.01833 & 8.57283 & 16.58660 \\
\hline Equity & $\begin{array}{l}\text { Equal variances not } \\
\text { assumed }\end{array}$ & & & 4.454 & 11.087 & .001 & 12.57971 & 2.82410 & 6.36986 & 18.78957 \\
\hline Equity & $\begin{array}{l}\text { Equal variances } \\
\text { assumed }\end{array}$ & $\begin{array}{r}2.79 \\
8\end{array}$ & .098 & -3.867 & 95 & .000 & -8.85025 & 2.28879 & -13.39408 & -4.30643 \\
\hline Assets & $\begin{array}{l}\text { Equal variances not } \\
\text { assumed }\end{array}$ & & & -8.155 & 42.970 & .000 & -8.85025 & 1.08528 & -11.03898 & -6.66153 \\
\hline Loans & $\begin{array}{l}\text { Equal variances } \\
\text { assumed }\end{array}$ & $\begin{array}{r}1.01 \\
7\end{array}$ & .316 & 5.524 & 95 & .000 & 18.15830 & 3.28688 & 11.63303 & 24.68357 \\
\hline Assets & $\begin{array}{l}\text { Equal variances not } \\
\text { assumed }\end{array}$ & & & 7.467 & 16.276 & .000 & 18.15830 & 2.43181 & 13.01020 & 23.30640 \\
\hline Deposits / & $\begin{array}{l}\text { Equal variances } \\
\text { assumed }\end{array}$ & $\begin{array}{r}4.54 \\
9\end{array}$ & .036 & 3.237 & 95 & .002 & 17.27616 & 5.33726 & 6.68036 & 27.87197 \\
\hline Assets & $\begin{array}{l}\text { Equal variances not } \\
\text { assumed }\end{array}$ & & & 2.717 & 11.687 & .019 & 17.27616 & 6.35960 & 3.37854 & 31.17378 \\
\hline
\end{tabular}

The independent $\mathrm{T}$ - test is used to compare the mean scores of two groups. In this case, we will see the significance of the differences between Islamic and Conventional banks. The results from the table above show that the Total Loan to Total Asset and Deposits to Total Asset for Islamic banks are less than those for Conventional banks and significant at $10 \%$ with mean difference of 18.15830 and 17.27616 respectively. Total Equity to Total Asset for Islamic banks is higher than that for Conventional banks and significant at $10 \%$ with mean difference of -8.85025 . Overall, we can conclude that all the three variables have significant difference between the mean of the two groups which are Islamic and Conventional banks for profitability. Then, H1 is accepted. 


\section{Regression}

Table 3. Conventional banks ROA

\begin{tabular}{|c|c|c|c|c|c|c|}
\hline \multicolumn{7}{|c|}{ ANOVA $^{\mathrm{a}, \mathrm{b}}$} \\
\hline & & Sum of Squares & df & Mean Square & $\mathrm{F}$ & Sig. \\
\hline \multirow{3}{*}{1} & Regression & 64.328 & 3 & 21.443 & 44.491 & $.000^{\mathrm{c}}$ \\
\hline & Residual & 39.521 & 82 & .482 & & \\
\hline & Total & 103.849 & 85 & & & \\
\hline
\end{tabular}

a. Dependent Variable: Return on Assets

b. Selecting only cases for which Type of Bank $=0$

c. Predictors: (Constant), Deposits / Assets, Loans / Assets, Equity / Assets

Coefficients $^{\mathrm{a}, \mathrm{b}}$

\begin{tabular}{|c|c|c|c|c|c|c|}
\hline \multirow{2}{*}{\multicolumn{2}{|c|}{ Model }} & \multicolumn{2}{|c|}{ Unstandardized Coefficients } & \multirow{2}{*}{$\begin{array}{c}\begin{array}{c}\text { Standardized } \\
\text { Coefficients }\end{array} \\
\text { Beta }\end{array}$} & \multirow[t]{2}{*}{$\mathrm{t}$} & \multirow[t]{2}{*}{ Sig. } \\
\hline & & B & Std. Error & & & \\
\hline \multirow{4}{*}{1} & (Constant) & 5.742 & .774 & & 7.421 & .000 \\
\hline & Equity / Assets & -.017 & .017 & -.118 & -1.003 & .319 \\
\hline & Loans / Assets & -.007 & .008 & -.066 & -.852 & .397 \\
\hline & Deposits / Assets & -.058 & .008 & -.848 & -6.919 & .000 \\
\hline
\end{tabular}

a. Dependent Variable: Return on Assets

b. Selecting only cases for which Type of Bank $=0$

The first table above shows that the three predictors simultaneously explain the ROA. However, and as shown in the second table, there is only one significant factor that influences the profitability of the Conventional banks, which is measured by the ROA. This factor is the Deposits to Total Asset and has a negative effect with beta coefficient of -.058 .

Therefore, $\mathrm{H} 1$ is accepted for Conventional banks ROA.

Table 4. Conventional banks ROE

\begin{tabular}{|rl|r|r|r|r|r|}
\hline Model & & Sum of Squares & df & Mean Square & F & Sig. \\
\hline \multirow{2}{*}{1} & Regression & 1089.214 & 3 & 363.071 & 16.076 & $.000^{c}$ \\
& Residual & 1851.942 & 82 & 22.585 & & \\
& Total & 2941.155 & 85 & & & \\
\hline
\end{tabular}

a. Dependent Variable: Return on Equity

b. Selecting only cases for which Type of Bank $=0$

c. Predictors: (Constant), Deposits / Assets, Loans / Assets, Equity / Assets

Coefficients ${ }^{\mathbf{a}, \mathbf{b}}$

\begin{tabular}{|c|c|c|c|c|c|c|}
\hline \multirow{2}{*}{\multicolumn{2}{|c|}{ Model }} & \multicolumn{2}{|c|}{ Unstandardized Coefficients } & \multirow{2}{*}{$\begin{array}{c}\begin{array}{c}\text { Standardized } \\
\text { Coefficients }\end{array} \\
\text { Beta }\end{array}$} & \multirow[t]{2}{*}{$\mathrm{t}$} & \multirow[t]{2}{*}{ Sig. } \\
\hline & & B & Std. Error & & & \\
\hline \multirow{4}{*}{1} & (Constant) & 43.926 & 5.297 & & 8.293 & .000 \\
\hline & Equity / Assets & -.809 & .119 & -1.033 & -6.809 & .000 \\
\hline & Loans / Assets & -.080 & .055 & -.145 & -1.460 & .148 \\
\hline & Deposits / Assets & -.296 & .057 & -.814 & -5.161 & .000 \\
\hline
\end{tabular}

a. Dependent Variable: Return on Equity

b. Selecting only cases for which Type of Bank $=0$

For ROE, there are two significant factors that influence profitability: Total Equity to Total Asset and Deposits to Total Assets. Both show negative effect and significant effect to the profitability of the Conventional banks with beta coefficients of -.809 and -.296 .

Therefore, $\mathrm{H} 1$ is accepted for ROE as well. 
Table 5. Islamic banks ROA

ANOVA $^{\mathrm{a}, \mathrm{b}}$

\begin{tabular}{|ll|r|r|r|r|r|}
\hline Model & Sum of Squares & df & Mean Square & F & Sig. \\
\hline \multirow{3}{*}{1} & Regression & 7.229 & 3 & 2.410 & .564 & $.656^{\mathrm{c}}$ \\
& Residual & 29.929 & 7 & 4.276 & & \\
& Total & 37.158 & 10 & & & \\
\hline
\end{tabular}

a. Dependent Variable: Return on Assets

b. Selecting only cases for which Type of Bank $=1$

c. Predictors: (Constant), Deposits / Assets, Loans / Assets, Equity / Assets

\begin{tabular}{|c|c|c|c|c|c|c|}
\hline \multicolumn{7}{|c|}{$\begin{array}{c}\text { Coefficients }^{\mathrm{a}, \mathrm{b}} \\
\end{array}$} \\
\hline \multirow{2}{*}{\multicolumn{2}{|c|}{ Model }} & \multicolumn{2}{|c|}{ Unstandardized Coefficients } & \multirow{2}{*}{$\begin{array}{c}\text { Standardized } \\
\text { Coefficients } \\
\text { Beta }\end{array}$} & \multirow[t]{2}{*}{$\mathrm{t}$} & \multirow[t]{2}{*}{ Sig. } \\
\hline & & $\mathrm{B}$ & Std. Error & & & \\
\hline \multirow{4}{*}{1} & (Constant) & -7.338 & 8.741 & & -.840 & .429 \\
\hline & Equity / Assets & .224 & .365 & .278 & .614 & .559 \\
\hline & Loans / Assets & -.036 & .095 & -.134 & -.382 & .714 \\
\hline & Deposits / Assets & .052 & .042 & .542 & 1.227 & .260 \\
\hline
\end{tabular}

a. Dependent Variable: Return on Assets

b. Selecting only cases for which Type of Bank $=1$

The above two table shows that the three independent variables do not influence the profitability of the Islamic banks measured in ROA neither simultaneously nor separately.

Therefore, $\mathrm{H} 1$ is not accepted for Islamic banks ROA.

Table 6. Islamic banks ROE

\begin{tabular}{|rl|r|r|r|r|r|}
\hline \multicolumn{2}{|c|}{ MNOVA $^{\mathbf{a}, \mathbf{b}}$} & \multicolumn{1}{c|}{ Sig. } \\
\hline \multirow{3}{*}{1} & Sum of Squares & df & Mean Square & F & Sig \\
& Regression & 179.904 & 3 & 59.968 & .643 & \\
& Residual & 653.150 & 7 & 93.307 & & \\
& Total & 833.054 & 10 & & & \\
\hline
\end{tabular}

a. Dependent Variable: Return on Equity

b. Selecting only cases for which Type of Bank $=1$

c. Predictors: (Constant), Deposits / Assets, Loans / Assets, Equity / Assets

Coefficients $^{\mathrm{a}, \mathrm{b}}$

\begin{tabular}{|c|c|c|c|c|c|c|}
\hline & \multirow[t]{2}{*}{ Model } & \multicolumn{2}{|c|}{ Unstandardized Coefficients } & \multirow{2}{*}{$\begin{array}{c}\begin{array}{c}\text { Standardized } \\
\text { Coefficients }\end{array} \\
\text { Beta }\end{array}$} & \multirow[t]{2}{*}{$\mathrm{t}$} & \multirow[t]{2}{*}{ Sig. } \\
\hline & & B & Std. Error & & & \\
\hline \multirow{4}{*}{1} & (Constant) & -38.609 & 40.833 & & -.946 & .376 \\
\hline & Equity / Assets & 1.161 & 1.703 & .305 & 682 & .517 \\
\hline & Loans / Assets & -.122 & .443 & -.095 & -.274 & .792 \\
\hline & Deposits / Assets & .264 & .196 & .587 & 1.346 & .220 \\
\hline
\end{tabular}

a. Dependent Variable: Return on Equity

b. Selecting only cases for which Type of Bank $=1$

The above two table shows that the three independent variables do not influence the profitability of the Islamic banks measured in ROE neither simultaneously nor separately.

Therefore, $\mathrm{H} 1$ is not accepted for Islamic banks ROE as well. 


\section{Correlation}

Table 7. Conventional banks ROA

\begin{tabular}{|c|c|c|c|c|c|}
\hline \multicolumn{6}{|c|}{ Correlations } \\
\hline & & Return on Assets & Equity / Assets & Loans / Assets & $\begin{array}{c}\text { Deposits / } \\
\text { Assets }\end{array}$ \\
\hline \multirow{3}{*}{ Return on Assets } & Pearson Correlation & 1 & $.600^{* * \pi}$ & $-.414^{* * \pi}$ & $-.782^{* *}$ \\
\hline & Sig. (2-tailed) & & .000 & .000 & .000 \\
\hline & $\mathrm{N}$ & 86 & 86 & 86 & 86 \\
\hline \multirow{3}{*}{ Equity / Assets } & Pearson Correlation & $.600^{* *}$ & 1 & $-.393^{* *}$ & $-.816^{* * *}$ \\
\hline & Sig. (2-tailed) & .000 & & .000 & .000 \\
\hline & $\mathrm{N}$ & 86 & 86 & 86 & 86 \\
\hline \multirow{3}{*}{ Loans / Assets } & Pearson Correlation & $-.414^{* *}$ & $-.393^{k *}$ & 1 & $.466^{* * *}$ \\
\hline & Sig. (2-tailed) & .000 & .000 & & .000 \\
\hline & $\mathrm{N}$ & 86 & 86 & 86 & 86 \\
\hline \multirow{3}{*}{ Deposits / Assets } & Pearson Correlation & $-.782^{* *}$ & $-.816^{* *}$ & $.466^{* * *}$ & 1 \\
\hline & Sig. (2-tailed) & .000 & .000 & .000 & \\
\hline & $\mathrm{N}$ & 86 & 86 & 86 & 86 \\
\hline
\end{tabular}

**. Correlation is significant at the 0.01 level (2-tailed).

The above table shows that for Conventional banks, there is a significant relationship between all the independent variables and ROA. For example, there is a positive correlation between Total Equity to Total Assets and ROA. Thus, it is .600 and is significant at $1 \%$.

Table 8. Conventional banks ROE

Correlations

\begin{tabular}{|c|c|c|c|c|c|}
\hline & & Return on Equity & Equity / Assets & Loans / Assets & $\begin{array}{c}\text { Deposits / } \\
\text { Assets }\end{array}$ \\
\hline \multirow{3}{*}{ Return on Equity } & Pearson Correlation & 1 & $-.312^{* * 4}$ & -.118 & -.038 \\
\hline & Sig. (2-tailed) & & .003 & .279 & .728 \\
\hline & $\mathrm{N}$ & 86 & 86 & 86 & 86 \\
\hline \multirow{3}{*}{ Equity / Assets } & Pearson Correlation & $-.312^{* *}$ & 1 & $-.393^{* *}$ & $-.816^{* *}$ \\
\hline & Sig. (2-tailed) & .003 & & .000 & .000 \\
\hline & $\mathrm{N}$ & 86 & 86 & 86 & 86 \\
\hline \multirow{3}{*}{ Loans / Assets } & Pearson Correlation & -.118 & $-.393^{* * *}$ & 1 & $.466^{* * 4}$ \\
\hline & Sig. (2-tailed) & .279 & .000 & & .000 \\
\hline & $\mathrm{N}$ & 86 & 86 & 86 & 86 \\
\hline \multirow{3}{*}{ Deposits / Assets } & Pearson Correlation & -.038 & $-.816^{* * *}$ & $.466^{* *}$ & 1 \\
\hline & Sig. (2-tailed) & .728 & .000 & .000 & \\
\hline & $\mathrm{N}$ & 86 & 86 & 86 & 86 \\
\hline
\end{tabular}

**. Correlation is significant at the 0.01 level (2-tailed).

For the Conventional correlation between independent variables and ROE, only Total Equity to Total Asset has a significant relationship. There is a negative relationship between ROE (dependent) and Total Equity to Total Asset (independent) at $1 \%$ significant level (-.312). It shows as well that Total Equity to Total Asset has relationship with profitability. Among the correlation tests between independent variables, we have a negative correlation at $1 \%$ significant level between Total Equity to Total Asset. Also, Deposits to Total Asset have - 816 . 
Table 9. Islamic banks ROA

Correlations

\begin{tabular}{|c|c|c|c|c|c|}
\hline & & Return on Assets & Equity / Assets & Loans / Assets & $\begin{array}{c}\text { Deposits / } \\
\text { Assets }\end{array}$ \\
\hline \multirow{3}{*}{ Return on Assets } & Pearson Correlation & 1 & -.101 & -.127 & .380 \\
\hline & Sig. (2-tailed) & & .767 & .710 & .250 \\
\hline & $\mathrm{N}$ & 11 & 11 & 11 & 11 \\
\hline \multirow{3}{*}{ Equity / Assets } & Pearson Correlation & -.101 & 1 & .247 & $-.639^{*}$ \\
\hline & Sig. (2-tailed) & .767 & & .465 & .034 \\
\hline & $\mathrm{N}$ & 11 & 11 & 11 & 11 \\
\hline \multirow{3}{*}{ Loans / Assets } & Pearson Correlation & -.127 & .247 & 1 & -.113 \\
\hline & Sig. (2-tailed) & .710 & .465 & & .740 \\
\hline & $\mathrm{N}$ & 11 & 11 & 11 & 11 \\
\hline \multirow{3}{*}{ Deposits / Assets } & Pearson Correlation & .380 & $-.639^{*}$ & -.113 & 1 \\
\hline & Sig. (2-tailed) & .250 & .034 & .740 & \\
\hline & $\mathrm{N}$ & 11 & 11 & 11 & 11 \\
\hline
\end{tabular}

*. Correlation is significant at the 0.05 level (2-tailed).

For the Islamic correlation between independent variables and ROA, there is no significant relationship. However, the correlation tests between independent variables shows that Total Equity to Total Asset and Deposits to Total Asset have positive correlation at 1\% significant level (.639).

Table 10. Islamic banks ROE

Correlations

\begin{tabular}{|c|c|c|c|c|c|}
\hline & & Return on Equity & Equity / Assets & Loans / Assets & $\begin{array}{c}\text { Deposits / } \\
\text { Assets }\end{array}$ \\
\hline \multirow{3}{*}{ Return on Equity } & Pearson Correlation & 1 & -.094 & -.086 & .403 \\
\hline & Sig. (2-tailed) & & .784 & .801 & .219 \\
\hline & $\mathrm{N}$ & 11 & 11 & 11 & 11 \\
\hline \multirow{3}{*}{ Equity / Assets } & Pearson Correlation & -.094 & 1 & .247 & $-.639^{*}$ \\
\hline & Sig. (2-tailed) & .784 & & .465 & .034 \\
\hline & $\mathrm{N}$ & 11 & 11 & 11 & 11 \\
\hline \multirow{3}{*}{ Loans / Assets } & Pearson Correlation & -.086 & .247 & 1 & -.113 \\
\hline & Sig. (2-tailed) & .801 & .465 & & .740 \\
\hline & $\mathrm{N}$ & 11 & 11 & 11 & 11 \\
\hline \multirow{3}{*}{ Deposits / Assets } & Pearson Correlation & .403 & $-.639^{*}$ & -.113 & 1 \\
\hline & Sig. (2-tailed) & .219 & .034 & .740 & \\
\hline & $\mathrm{N}$ & 11 & 11 & 11 & 11 \\
\hline
\end{tabular}

*. Correlation is significant at the 0.05 level (2-tailed).

Similarly, in the above part, there is no significant relationship between any of the independent variables and ROE for the Islamic banks. However, the correlation tests between independent variables shows that Total Equity to Total Asset and Deposits to Total Asset have positive correlation at 1\% significant level (.639).

Table 11. Summary of Correlation between Independent and Dependent Variables

\begin{tabular}{|c|c|c|c|c|}
\hline & \multicolumn{2}{|c|}{ Conventional Banks } & \multicolumn{2}{|c|}{ Islamic Banks } \\
\hline Independent Variables & ROA & ROE & ROA & ROE \\
\hline Equity to Assets & positive & negative & negative & negative \\
\hline Loans to Assets & negative & negative & negative & negative \\
\hline Deposits to Assets & negative & negative & negative & positive \\
\hline
\end{tabular}

\section{Conclusion and Recommendations}

The purpose of this study was to determine the factors of profitability of Islamic banks compared with those of conventional banks operating in Lebanon between 2012 and 2016 by applying regression analysis. This study has employed three internal factors to assess their relationship with profitability determined by ROA and ROE. These internal factors are: capital adequacy, loans to assets, and deposits to assets. 
The regression variables interacted differently with the profitability indicators in Islamic and conventional banking. First, there is only one significant factor, Deposits to Total Asset, that influences the profitability of the conventional banks but it does not influence the profitability of the Islamic banks measured in ROA neither simultaneously nor separately. This indicates that deposits contribute to the profitability of conventional banks. Secondly, the two significant factors, total equity and total loans, have a negative impact on the profitability of conventional banks and do not affect the profitability of Islamic banks measured in ROE neither simultaneously nor separately. This suggests that high capital ratios and lending improve profitability of conventional banks. The results also show the difference in relationships between the Bank's characteristics and performance indicators.

Although the results show that there is a significant relationship between all the independent variables and ROA for conventional banks, there is no significant relationship between independent variables and ROA for Islamic banks. Moreover, for the Conventional correlation between independent variables and ROE, only Total Equity to Total Asset has a significant relationship. There is a negative relationship between ROE (dependent) and Total Equity to Total Asset, whereas there is no significant relationship between any of the independent variables and ROE for the Islamic banks.

Therefore, we can conclude that comparing the profitability of the Islamic and conventional banks operating in Lebanon shows that conventional banks are on average more profitable than Islamic ones. Results show that conventional banks are better in liquidity than Islamic ones. Liquidity indicators, total deposit, and total loans are higher in Conventional banks. On the contrary, capital adequacy is better in Islamic banks than conventional ones indicating that Islamic banks are more able to absorb losses and handle risk exposure with shareholders than conventional ones. The above results could be contributed to the fact that Islamic banks in Lebanon are relatively very few and younger compared to Lebanese conventional banks and therefore they are under the low profit stage. That result leads us to expect Islamic banks to perform better than conventional banks once they enter their high growth stage.

Moreover, this study provides a different picture of financial intermediation in Lebanon. Although there are some differences in Conventional and Islamic banking activities, the profitability conditions remain similar. In addition, Islamic banking should not be viewed as a religious movement, but as a supplementary system for conventional banking in Lebanon.

\section{References}

Al-Ghussein, R., \& Nshwati, M. A. (2014) Evaluating the Financial Performance of Jordanian Islamic and Conventional Banks, Using the Indicators of the "CAMEL" Method: A Comparative Analysis. Tishreen University Journal for Research and Scientific Studies -Economic and Legal Sciences Series, 36(1), 341-361.

Al-Kassim, F. (2005). The Profitability of Islamic and Conventional Banking in the GCC Countries: A Comparative Study. Journal of Review of Islamic Economics, 13, 5-30.

Al-Sarouji. (2004) Comparative Performance of Islamic and Traditional Banks Using Financial Ratios. Alyarmouk University, MBA thesis.

Al-Tamimi, H. A. (2005). The Determinants of the UAE Commercial Banks' Performance: A Comparison of the National and Foreign Banks. Journal of Transnational Management, 10(4), 35-47. https://doi.org/10.1300/J482v10n04_03

Bashir, A. H. (2003). Determinants of Profitability in Islamic Banks: Some Evidence from the Middle East. Islamic Economic Studies, 11(1), 31-57.

Bourdima, S. (2014). Assessing Financial Performance of Islamic Banks Using Financial Ratios (Al Baraka International Group from 2011-2013. Journal of University 08 May 1945 Gulma Algeria, Faculty of Economic Sciences and Management Sciences, 4(2), 21-33.

Bourke, P. (1989.). Concentration and other Determinants of Bank Profitability in Europe. Journal of Banking and Finance, 13(1), 65-80. https://doi.org/10.1016/0378-4266(89)90020-4

Demirgüç, K., \& Huizinga, H. (1999). Determinants of commercial bank interest margins and profitability: Some international evidence. The World Bank Economic Review, 13(2), 379-408. https://doi.org/10.1093/wber/13.2.379

Dietrich, A., \& Wanzenried, G. (2009). What Determines the Profitability of Commercial Banks? New Evidence from Switzerland. 12th Conference of the Swiss Society for Financial Market Researches, Geneva.

Driver, R., \& R. Windram (2007). Public Attitudes to Inflation and Interest Rates. Bank of England, Quarterly 
Bulletin, 47(2), 208-223.

Elyor, S. (2009). Factors Affecting the Performance of Foreign Banks in Malaysia. Master's Degree Thesis, University of Utara, Malaysia.

Goddard, J., Molyneux, P., \& Wilson, J. O. S. (2004). Dynamics of Growth and Profitability in Banking. Journal of Money, Credit and Banking, 36, 1069-1090. https://doi.org/10.1353/mcb.2005.0015

Gul, S., Irshad, F., \& Zaman, K. (2011). Factors Affecting Bank Profitability in Pakistan, The Romanian Economic Journal, 14(39), 61-83.

Ika, S. R., \& Abdullah, N. (2011). A Comparative Study of Financial Performance of Islamic Banks and Conventional Banks in Indonesia. International Journal of Business and Social Science, 2(15), 199-207.

Khediri, K. B., Charfeddine, L., \& Youssef, S. B. (2015). Islamic versus conventional banks in the GCC countries: A comparative study using classification techniques. Research in International Business and Finance, 33, 75-98. https://doi.org/10.1016/j.ribaf.2014.07.002

Khrawish, H. A. (2011). Determinants of commercial banks performance: evidence from Jordan. International Research Journal of Finance and Economics, 81, 148-159.

Masruki, R., Ibrahim, N., Osman, E., \& Abdul, W. H. (2011). Financial Performance of Malaysian Founder Islamic Banks Versus Conventional Banks. Journal of Business and Policy Research, 6(2), 67-79.

Moore, B. J. (1986). Inflation and Financial Deepening. Journal of Development Economics, 20, $125-133$. https://doi.org/10.1016/0304-3878(86)90008-8

Onakoya, A. B., \&, Onakoya, A. O. (2013). The Performance of Conventional and Islamic Banks in the United Kingdom: A Comparative Analysis. Journal of Research in Economics and International Finance, 2(2), 29-38.

Pasiouras, F., \& Kosmidou, K. (2007). Factors influencing the profitability of domestic and foreign commercial banks in the European Union. Research in International Business \& Finance, 21(2), 222-237. https://doi.org/10.1016/j.ribaf.2006.03.007

Ramlan, H., \& Adnan, M. (2016). The Profitability of Islamic and Conventional Bank: Case Study in Malaysia. Procedia economic and finance, 35, 359-367. https://doi.org/10.1016/S2212-5671(16)00044-7

Sadaqat, M. S., Akhtar, M. F., \& Ali, K. (2011). An Analysis on the Performance of IPO - A Study on the Karachi Stock Exchange of Pakistan. "International Journal of Business and Social Science", 2(6), 275-285.

Saksonova, S., \& Solovjova, I. (2011). Analysis of The Quality and Profitability of Assets in The Banking System and The Impact of Macroeconomic Factors On Its Stability-Case of Latvia. International Conference On Applied Economics, 537-548.

Scott, J. W., \& Arias, J. C. (2011). Banking profitability deteminants. Business Intelligence Journal, 4(2), 209-230.

Srairi, S. A. (2009). Factors Influencing the Profitability of Conventional and Islamic Commercial Banks in GCC Countries. Review of Islamic Economics, 13(1), 5-30.

Sufian, F. (2011). Profitability of The Korean Banking Sector: Panel Evidence On Bank- Specific and Macroeconomic Determinants. Journal of Economics and Management, 7(1), 43-72.

Sufian, F., \& M. Habibullah, (2009). Bank Specific and Macroeconomic Determinants of Bank Profitability: Empirical Evidence from the China Banking Sector. Frontiers of Economics in China, 4(2), $274-291$. https://doi.org/10.1007/s11459-009-0016-1

Wasiuzzaman, S., \& H. Ahmed Tarmizi, (2010). Profitability of Islamic Banks in Malaysia: An Empirical Analysis. Journal of Islamic Economics, Banking and Finance, 6(4), 51-68.

\section{Copyrights}

Copyright for this article is retained by the author(s), with first publication rights granted to the journal.

This is an open-access article distributed under the terms and conditions of the Creative Commons Attribution license (http://creativecommons.org/licenses/by/4.0/). 